\title{
A vedação do bis in idem no direito brasileiro: algumas \\ reflexões e uma proposta de interpretação
}

\author{
Rodrigo Tostes de Alencar Mascarenhas \\ Pontifícia Universidade Católica do Rio de Janeiro, Programa de Pós-Graduação em \\ Direito, Rio de Janeiro/RJ, Brasil. E-mail: rodrigomascarenhas@pge.rj.gov.br
}

\section{Resumo}

A aplicação da vedação do bis in idem ("VBI") foi dificultada quando o direito penal deixou de ser o único sistema punitivo relevante, aumentando a possibilidade de dupla punição pelos mesmos fatos. Outro desafio decorre do enfraquecimento da VBI pela necessidade de proteção reforçada de bens jurídicos sensíveis. Esta dificuldade é ampliada no Brasil com o surgimento de novos sistemas de apuração de responsabilidade que dificilmente podem ser denominados de administrativos (como é o caso da lei de improbidade). Ademais, a Constituição Brasileira não tem texto expresso reconhecendo a VBI, mas tem dispositivos relativos à tutela de bens sensíveis que o afastam. Assim, partindo dos tratados que vinculam o Brasil, analisando a jurisprudência brasileira e internacional sobre a VBI e discutindo a sobreposição de sistemas punitivos destinados à proteção de bens sensíveis, este trabalho tenta chegar a uma definição sobre o conteúdo da VBI no Brasil.

Palavras-chave

Vedação do bis in idem, sistemas punitivos penais e não penais, bens jurídicos ultrassensíveis.

\section{The "ne bis in idem" (double jeopardy) principle in Brazilian Law}

\begin{abstract}
The application of the ne bis in idem principle ("VBI"), started to grow on complexity when criminal law ceased to be the only relevant punitive system, increasing the possibility of double jeopardy, and when it was weakened due to the necessity to increase the protection of certain highly sensitive rights. In Brazil, that complexity is reinforced with the creation of completely new non criminal punitive procedures (as is the case with Brazilian improbity Act). Moreover, the text of The Brazilian Constitution does not mention the VBI, but has some clauses restricting its application on certain sensitive matters. In this work, beginning with an analysis of the applicable international treaties and of Brazilian and international courts jurisprudences on VBI, we discuss the overlap protection of sensitive matters by different punitive procedures trying to reach a definition of VBI in Brazil.
\end{abstract}




\section{Keywords}

Ne bis in idem, criminal and non-criminal procedures, protection of highly sensitive matters

\section{Sumário}

Introdução; 1. A base normativa da VBI; 2. A justificativa da VBI e as divergências sobre seu conteúdo; 3. Um problema inesperado: o surgimento e crescimento de novos esquemas punitivos; 4. Um problema ampliado: a sobreposição de esquemas de responsabilização de bens jurídicos supersensíveis; 5. A VBI na jurisprudência internacional; 6. A síntese possível; Referências.

\section{Introdução}

Nos últimos anos o Brasil tem assistido a um movimento de ampliação do enfrentamento à corrupção em distintas dimensões. Podemos falar de uma ampliação da ação de cada um dos possíveis atores (ministério público, tribunais de contas e advocacia pública); podemos falar da entrada de novos atores (como a Controladoria Geral da União); da introdução de novos instrumentos jurídicos em sistemas clássicos de apuração de responsabilidade (como é o caso da delação premiada em relação à responsabilidade penal) e podemos falar também da criação de novos sistemas de apuração de responsabilidade, como é o caso daquele trazido pela Lei n. 12.846/13, conhecida como "Lei anticorrupção".

Se este movimento gera aspectos extremamente positivos, ele também traz um desafio ao direito, consistente em tratar o problema da possível sobreposição de sanções tendo por base os mesmos fatos. Para lidar com este problema o direito tradicionalmente lança mão do (em geral) denominado princípio da vedação do bis in idem que, no Brasil, goza de situação peculiar: todos reconhecem sua existência em tese, pouco se discute sobre seu conteúdo de forma mais aprofundada e raramente ele é aplicado no caso concreto.

Saber o que é o bis in idem ou a vedação do bis in idem, ou princípio do non bis in idem, ou do ne bis in idem, que denominaremos aqui, a bem da economia de espaço, de VBI, é desafiador. Em primeiro lugar, como bem aponta Helena Regina Lobo da Costa, "a proibição de bis in idem apresenta características de regra, ou seja, é norma com alto grau 
de concretude"1 ${ }^{1}$. Aliás, quando expressamente adotado em tratados internacionais (como veremos a seguir), sua estrutura é indubitavelmente de regra.

Quanto a seu conteúdo a primeira resposta é a de que se trata de regra que veda que alguém seja "responsabilizado" mais de uma vez pelo mesmo fato. A equivocidade do termo "responsabilidade" vem a calhar pois uma das questões é saber se aquilo que é vedado é uma segunda punição pelo mesmo fato ou um segundo processo (tendente a uma punição), pelo mesmo fato. $E$, se a proibição for a de responder a um segundo processo, ela incide apenas se o beneficiário tiver sido punido no primeiro ou também incide se tiver sido absolvido²? Ademais, aquilo que (segundo a VBI) não pode ser objeto de uma segunda responsabilização é efetivamente um mesmo fato ${ }^{3}$ ou uma mesma hipótese de incidência?

Questão igualmente difícil - e que constitui o principal objeto deste trabalho - é saber se a VBI opera apenas dentro de cada sistema de responsabilidade punitiva (penal, administrativo, de improbidade), proibindo, portanto, duas punições ${ }^{4}$ criminais pelo

${ }^{1}$ COSTA, Helena Regina Lobo da. Ne bis in idem e Lei Anticorrupção: sobre os limites para a imposição de sanção pelo Estado. Revista Fórum de Ciências Criminais, Belo Horizonte, ano 2, n. 3, p. 79, jan./jun. 2015. Prossegue a autora lembrando que embora tradicionalmente tal regra seja denominada de princípio "o relevante é deixar claro que não existe um espaço para cláusulas de reserva em sua aplicação". (Idem, ibidem). Na mesma linha segue Jean Pradel, que, em sua obra sobre direito penal comparado, afirma que "A regra de que ninguém pode ser punido duas vezes pela mesma infração é geral”. PRADEL, Jean. Droit penal compare. 3 ed. Paris: Dalloz, 2008, p. 474 (embora em outras partes de sua obra ele se refira ao princípio do non bis in idem). Ressaltamos que, ao optar por tratar a VBI como regra, estamos alterando nossa posição, defendida em trabalho anterior, na qual tratamos a "VBI" como um princípio. MASCARENHAS, Rodrigo Tostes de Alencar. Notas sobre a aplicação do princípio da vedação do bis in idem entre processos de apuração de responsabilidade de distintas naturezas. In: COUTINHO Francisco Pereira e GRACIA, Julia (Coord.). Atas do I Curso sobre Mecanismos de Prevenção e Combate à Corrupção na Administração Pública. Lisboa: Ed. Universidade Nova De Lisboa, 2019, p. 43-70.

${ }^{2}$ A posição majoritária, ao menos fora do Brasil, entende que a VBI proíbe um segundo processo mesmo nos casos em que a pessoa tenha sido absolvida. No entanto, existem certas condições em que uma absolvição não gerará a proteção da $\mathrm{VBI}$, em especial quando tenham sido descobertos fatos novos ou quando tenha havido alguma falha procedimental que tenha impedido o seu curso regular. Esta posição acabou sendo, no contexto europeu, positivada pelo artigo 4 ㅇ do Protocolo $\mathrm{n}^{\circ}$ 7 à Convenção Europeia de Direitos Humanos, que tem a seguinte redação:

Direito a não ser julgado ou punido mais de uma vez

1. Ninguém pode ser penalmente julgado ou punido pelas jurisdições do mesmo Estado por motivo de uma infracção pela qual já foi absolvido ou condenado por sentença definitiva, em conformidade com a lei e o processo penal desse Estado.

2. As disposições do número anterior não impedem a reabertura do processo, nos termos da lei e do processo penal do Estado em causa, se factos novos ou recentemente revelados ou um vício fundamental no processo anterior puderem afectar o resultado do julgamento.

${ }^{3}$ Tampouco é trivial (mas foge ao escopo deste trabalho), saber em várias situações o que constitui ou não um mesmo fato.

${ }^{4}$ Registre-se que uma punição pode se desdobrar em mais de uma consequência negativa (prisão e multa ou perda do cargo e multa), sem que haja violação à VBI, desde que tais consequências sejam previstas como decorrência de uma (mesma) condenação decorrente de um mesmo (e único) processo. 
mesmo fato, mas permitindo que a uma punição penal se some uma punição não penal (administrativa por exemplo), pelo mesmo fato. Ou será que, uma vez definida sua hipótese de incidência, a proibição se dirige a qualquer segunda punição (ou segundo processo), independentemente de sua origem.

Antes de entrar no objeto central deste trabalho façamos uma breve análise da base normativa da VBI.

\section{A base normativa da VBI}

Não há, no direito interno brasileiro, base normativa expressa para a VBI. Com efeito, embora sua presença entre nós seja reconhecida de forma talvez unânime pela doutrina ${ }^{5}$ e jurisprudência (as divergências evidentemente se dão quanto a seu conteúdo) a VBI, ao contrário de vários países onde tem previsão constitucional expressa ${ }^{6}$, não está prevista nem na Constituição nem na legislação infraconstitucional, salvo nas hipóteses em que é afastada sem ser expressamente mencionada (como veremos mais à frente). Na verdade, a única "previsão" ou abertura constitucional pode ser encontrada no § 2ㅇ do artigo 5ㅇ da Constituição Brasileira, segundo o qual os "direitos e garantias expressos" na Constituição "não excluem outros decorrentes do regime e dos princípios por ela adotados, ou dos tratados internacionais" em que o Brasil seja parte ${ }^{7}$.

${ }^{5}$ Por exemplo, escrevendo sobre improbidade administrativa, José Roberto Pimenta Oliveira afirma que: "a Constituição já traz diversos princípios constitucionais materiais e formais, informativos e limitadores do exercício do jus puniendi estatal. (...). Sob o ponto de vista formal (ou processual punitivo), exige-se observância dos seguintes princípios: (...) (viii) princípio da vedação ao bis in idem". OLIVEIRA, José Roberto Pimenta. Improbidade administrativa e sua autonomia constitucional. Belo Horizonte: Fórum, 2009, p. 202.

${ }^{6}$ Dentre as quais: a Constituição Portuguesa, onde está previsto da seguinte forma: "Ninguém pode ser julgado mais do que uma vez pela prática do mesmo crime” (art. 29 '6'); a Lei Fundamental de Bonn, onde está previsto da seguinte forma: "Ninguém pode ser punido mais de uma vez pelo mesmo fato, com base no direito penal comum" (art. 103 (3); a Constituição dos E.U.A., onde está inserido na 5a emenda: "nor shall any person be subject for the same offense to be twice put in jeopardy of life or limb;"; a Constituição da África do Sul, que estabelece, no § 35 do Capítulo 2 o seguinte: “(3) Every accused person has a right to a fair trial, which includes the right: (...) (m) not to be tried for an offence in respect of an act or omission for which that person has previously been either acquitted or convicted" e a Constituição da Colômbia "Artículo 29. El debido proceso se aplicará a toda clase de actuaciones judiciales y administrativas. (...). Quien sea sindicado tiene derecho a la defensa y (...) no ser juzgado dos veces por el mismo hecho".

7 Vale mencionar o caso da França, onde o VBI tampouco tem previsão expressa na constituição. No entanto, a proteção dada pelo $\mathrm{VBI}$ acabou sendo viabilizada inicialmente pela aplicação do artigo 8으 da Declaração dos Direitos do Homem e do Cidadão (que integra a Constituição Francesa), e que determina que a lei só pode estabelecer penas "estrita e evidentemente necessárias" ("La Loi ne doit établir que des peines strictement et évidemment nécessaires"). Posteriormente a aplicação da VBI foi garantida pela Convenção Europeia de Direitos Humanos, que será tratada mais à frente. Sobre o tema PRADEL, Jean. Droit penal compare. 3 ed. Paris: Dalloz, 2008, p. 482-483 e GUYOMAR, Mattias. Les sanctions administratives. Paris: LGDJ, 2014, p. 118-125. No Reino Unido a VBI também não é expressamente reconhecida, mas proteção equivalente acaba por seu alcançada

Revista Publicum

Rio de Janeiro, v. 6, n. 1, p. 13-41, 2020

http://www.e-publicacoes.uerj.br/index.php/publicum

DOI: 10.12957/publicum.2020.57571 
A principal previsão da VBI no direito brasileiro $^{8}$ se encontra no artigo 8ㅇ da Convenção Americana sobre Direitos Humanos, conhecida como Pacto de São José da Costa Rica, de 22 de novembro de $1969^{9}$, com o seguinte texto:

“Artigo 8 - Garantias judiciais

2. Toda pessoa acusada de um delito $\underline{10}$ tem direito a que se presuma sua inocência, enquanto não for legalmente comprovada sua culpa. Durante o processo, toda pessoa tem direito, em plena igualdade, às seguintes garantias mínimas: (...)

12. O acusado absolvido por sentença transitada em julgado não poderá ser submetido a novo processo pelos mesmos fatos".

Ainda na esfera internacional temos o artigo 14 "7" do Pacto Internacional sobre Direitos Civis e Políticos ${ }^{11}$, adotado pela XXI Sessão da Assembleia-Geral das Nações Unidas, em 16 de dezembro de 1966, com a seguinte redação: “Ninguém poderá ser processado ou punido por um delito pelo qual já foi absolvido ou condenado por sentença passada em julgado, em conformidade com a lei e os procedimentos penais de cada país"12.

Uma vista d'olhos nesses dois tratados internacionais já revela uma diversidade de tratamento quanto àquilo que não pode ser objeto de dupla responsabilização: mesmo fato ou mesmo delito, diversidade que também se encontra nos textos constitucionais que tratam explicitamente da VBI. Considerando que ambas as convenções fazem parte do direito brasileiro a única solução que nos parece possível é considerar a posição mais protetiva (que impede dupla responsabilização pelos mesmos fatos).

Importante registrar que a VBI também é reconhecida no contexto da cooperação penal internacional ${ }^{13}$ e está expressamente previsto no Estatuto de Roma do Tribunal Penal Internacional ${ }^{14}$.

(embora nem sempre) por outros meios, incluindo a possibilidade de um mesmo órgão ser responsável por iniciar processos de responsabilização penal ou não penal pelo mesmos fatos. É o que acontece com o Inland Revenue, responsável pela arrecadação de impostos diretos que, segundo Jean Pradel, quando obtém uma condenação penal, não aplica sanções administrativas pelos mesmos fatos (Op. Cit., p. 481-482).

8 Estamos aqui "tangenciando" a polêmica que separa os "monistas" e "dualistas" no campo do direito internacional.

${ }_{9}^{9}$ Promulgada no Brasil pelo Decreto n. 678, de 06.11.1992.

10 Vale observar que nas versões em português e em espanhol se usa a palavra "delito". Já na versão em inglês se usa a expressão "criminal offense".

11 Promulgado no Brasil pelo Decreto n. 592, de 06.07.1992.

${ }^{12}$ A versão em inglês é: No one shall be liable to be tried or punished again for an offence for which he has already been finally convicted or acquitted in accordance with the law and penal procedure of each country.

13 "The principle that no one shall be tried or punished more than once for the same offence, expressed as ne bis in idem or double jeopardy, is reflected in the major human rights treaties, and is an expression of the broader principle of finality and the binding effect of judgments (...). The principle also applies in the context of international cooperation in criminal matters". No entanto, os autores esclarecem que, a rigor, a decisão do tribunal de um país não pode ser considerada como 


\section{A justificativa da VBI e as divergências sobre seu conteúdo}

O que justifica a VBI é uma ideia de justiça, de razoabilidade ou de proporcionalidade. As pessoas devem se responsabilizar pelo que fizeram, mas não seria justo "se responsabilizar duas vezes". Akhil Amar, tratando da VBI no bill of rights da Constituição dos E.U.A., afirma que uma de suas justificativas é evitar o tipo de "cara ou coroa", na qual o Estado-acusador diz ao acusado: "se der cara nós ganhamos, se der coroa jogaremos novamente até você perder"15. Assim, além da ideia de justiça também é possível invocar um interesse em que o trabalho de investigação e preparação das investigações seja bem feito $^{16}$.

Canotilho e Vital Moreira, ao comentarem o dispositivo da Constituição Portuguesa que trata da $\mathrm{VBI}^{17}$, que tratam como princípio, afirmam que ele:

"comporta duas dimensões: (a) como direito subjetivo fundamental, garante ao cidadão o direito de não ser julgado mais do que uma vez pelo mesmo facto, conferindo-lhe ao mesmo tempo a possibilidade de se defender contra actos estaduais violadores deste direito (direito de defesa negativo); (b) como princípio

vinculante do tribunal de outros países (sob pena de violação de sua soberania) e que, por isso, existe enorme variação quanto à forma e extensão que distintos países dão a julgamentos proferridos por outros. CRYER, Robert, FRIMAN, Håkan, ROBINSON, Darryl, WILMSHURST, Elizabeth. An Introduction to International Criminal Law and Procedure. 3 ed, reprinted. Cambridge: Cambridge University Press, 2015, p. 85 e ss.

14 Promulgado no Brasil pelo Decreto 4.388 de 25 de setembro de 2002 (artigos 20 e 89):

Artigo 20 Ne bis in idem

1. Salvo disposição contrária do presente Estatuto, nenhuma pessoa poderá ser julgada pelo Tribunal por atos constitutivos de crimes pelos quais este já a tenha condenado ou absolvido.

2. Nenhuma pessoa poderá ser julgada por outro tribunal por um crime mencionado no artigo $5^{\circ}$, relativamente ao qual já tenha sido condenada ou absolvida pelo Tribunal.

3. O Tribunal não poderá julgar uma pessoa que já tenha sido julgada por outro tribunal, por atos também punidos pelos artigos 6으, 7o ou 8ㅇ, a menos que o processo nesse outro tribunal:

a) Tenha tido por objetivo subtrair o acusado à sua responsabilidade criminal por crimes da competência do Tribunal; ou

b) Não tenha sido conduzido de forma independente ou imparcial, em conformidade com as garantias de um processo equitativo reconhecidas pelo direito internacional, ou tenha sido conduzido de uma maneira que, no caso concreto, se revele incompatível com a intenção de submeter a pessoa à ação da justiça.

Artigo 89 Entrega de Pessoas ao Tribunal

1. O Tribunal poderá dirigir um pedido de detenção e entrega de uma pessoa (...).

2. Sempre que a pessoa cuja entrega é solicitada impugnar a sua entrega perante um tribunal nacional com base no princípio ne bis in idem previsto no artigo 20, o Estado requerido consultará, de imediato, o Tribunal para determinar se houve uma decisão relevante sobre a admissibilidade. Se o caso for considerado admissível, o Estado requerido dará seguimento ao pedido. Se estiver pendente decisão sobre a admissibilidade, o Estado requerido poderá diferir a execução do pedido até que o Tribunal se pronuncie".

15 AMAR Akhil Reed. The Bill of Rights: Creation and Reconstruction. New Haven \& London: Yale University Press, 1998, p. 116.

16 "Reasons of fairness to defendants and the interest of thorough investigations and preparations of cases by the prosecutorial authorities motivate the principle". CRYER, Robert, FRIMAN, Håkan, ROBINSON, Darryl, WILMSHURST, Elizabeth. An Introduction to International Criminal Law... Op. cit, p. 85.

17 Art. $29^{\prime}$ '6', reproduzido na nota 6. 
constitucional objectivo (dimensão objectiva do direito fundamental), obriga fundamentalmente o legislador à conformação do direito processual e à definição do caso julgado material, de modo a impedir a existência de vários julgamentos pelo mesmo facto". 18

Ao tratar do conteúdo da VBI é muito importante fazer a distinção entre consequência punitiva (penal ou de outra natureza) e consequência reparatória. Existe um consenso razoável no sentido de que a VBI veda uma segunda punição (ou um segundo processo tendente a uma punição) mas não atinge a possibilidade de cumulação de uma obrigação de reparar um dano e de uma punição. A reparação de um dano deve servir apenas para repor uma pessoa ou um bem jurídico à situação em que ela se encontrava antes de um dano, retomando-se o denominado status quo ante ${ }^{19}$. Ainda que esta reparação possa ter um custo financeiro, pagar por este custo não é uma punição, inclusive porque, dependendo das condições econômicas do agente ou do montante envolvido este custo pode ser irrelevante. Já a consequência punitiva, com escusas pela redundância, visa a punir ou "castigar" alguém por ter feito algo, independentemente de qualquer possibilidade de retorno ao status quo ante ${ }^{20}$.

Por outro lado, a possibilidade de um mesmo fato gerar uma punição penal e uma punição de outra natureza é (ou era) aceita por boa parte da doutrina e jurisprudência, tanto na França ${ }^{21}$ como em Portugal, onde os mesmos Canotilho e Vital Moreira consideram que: “Não se reconduz à 'prática do mesmo crime' o sancionamento de uma conduta como infração disciplinar e como crime (...) e como crime e como contraordenação"22.

No Brasil, ao contrário do que ocorre por exemplo em Portugal, não existe uma lei geral sobre direito administrativo sancionador. Pois bem, a Lei Portuguesa (Decreto-Lei no 433/82), denominada de Regime Geral das Contra-Ordenações - RGCO, possui dispositivo

${ }^{18}$ CANOTILHO, J. J. Gomes MOREIRA, Vital. Constituição da República Portuguesa: anotada Vol. I, 4 ed. Reimpressão. Coimbra: Coimbra Editora, 2014, p. 497. Importante ressaltar que a parte final da citação revela a importância do instituto da coisa julgada como instrumento de viabilização da VBI (ao menos no interior de cada sistema de responsabilização).

${ }^{19}$ Sobre o tema veja-se SCHREIBER, Anderson. Novos Paradigmas da Responsabilidade Civil. 6 ed. São Paulo: Atlas, 2015.

${ }^{20}$ A razão ou objetivo que se busca com a punição é objeto de um mais do que centenário debate no direito penal, na sociologia do direito na filosofia e em outros campos. Sobre o tema vide GARAPON, Antoine, GROS Fréderic, PECH, Thierry. Punir em democracia - E a Justiça será. Lisboa: Instituto Piaget, 2002. Um resumo da doutrina brasileira sobre o tema e sua aplicação específica ao direito administrativo sancionador se encontra em VORONOFF. Alice. Direito Administrativo Sancionador no Brasil. Justificação, Interpretação e Aplicação. Belo Horizonte: Fórum, 2018, Capítulo 3. Vide ainda VENÂNCIO, Denilson Marcondes. Non Bis in idem e as Sanções Administrativas por Improbidade e Penal. Revista Trimestral de Direito Público, n. 61, p. 161-186, 2015, p. 180-182.

${ }^{21}$ Vide nota 7 acima.

22 Op. Cit., p. 498. "Contra-ordenação" é a denominação que o direito português dá às infrações administrativas. 
específico (artigo Artigo 20\%), afirmando que "se o mesmo facto constituir simultaneamente crime e contra-ordenação, será o agente sempre punido a título de crime, sem prejuízo da aplicação das sanções acessórias previstas para a contraordenação".

Comentando este dispositivo, Augusto Silva Dias lembra que o Tribunal Constitucional Português, em caso em que estava em causa interpretação de certo dispositivo legal "no sentido de admitir que a mesma factualidade comporte uma punição simultaneamente a título de crime e de contra-ordenação ... concluiu que 'o princípio ne 'bis in idem' ... pode ter aplicação, por analogia em concurso de crimes e contraordenações, quando os bens jurídicos tutelados pelas respectivas normas sejam idênticos. No fundo, é o reconhecimento de que estão em causa os mesmos bens jurídicos nas infracções correspondentes a factos que, pelo mesmo diploma ... 'constituem simultaneamente crime e contra-ordenação'”23. Dias relata ainda que em acórdão posterior, o "Tribunal reforça esta orientação vincando que 'não basta invocar a punição plural de um facto ou acção unitários para se ter como demonstrada uma violação do no. 5 do artigo 29ำ da Constituição' sendo necessário que 'as normas sancionem - de modo duplo ou múltiplo - substancialmente a mesma infracção' e acrescentando ao critério da identidade do bem jurídico tutelado um outro, alternativo, constituído pelo 'desvalor pressuposto por cada uma' das normas sancionadoras concorrentes'”. Conclui o autor que "a contrario" "quando a unidade de facto não é acompanhada por uma unidade de fundamento a contra-ordenação conserva autonomia punitiva e justifica-se a aplicação da coima $^{24}$ a par da pena" 25 .

Na doutrina brasileira, Sandro Lucio $\operatorname{Dezan}^{26}$ e José Roberto Pimenta Oliveira ${ }^{27}$ admitem amplamente a cumulação de punições de distintos sistemas de responsabilização pelo mesmo fato. Em sentido contrário, temos a posição de Helena

${ }^{23}$ DIAS, Augusto Silva. Direito das contra-ordenações. Coimbra: Almedina, 2018, p. 158-159.

24 "Coima" é a denominação que o direito português dá às multas administrativas.

${ }^{25}$ Idem, p. 159.

26 "Anote-se que não haverá ofensa ao princípio em comento no caso de, pelo mesmo fato, ser o agente público punido em sede de direito penal e em sede de direito disciplinar, ou mesmo em sede de direito civil a exemplo da reparação do dano, pois a independência (relativa) das instâncias, por se tratarem de ramos distintos do direito sancionador, regulado por normas distintas e dando azo a sanções diferenciadas, compatibiliza o sistema jurídico, para tal permissão, que desfruta do status da constitucionalidade e da legalidade." DEZAN, Sandro Lucio. Direito administrativo disciplinar: Princípios fundamentais, Curitiba: Juruá, 2013, p. 264.

27 "Não veda o princípio tratado da possibilidade de cumulação de sanções pela prática da mesma conduta ilícita, Proíbe-se, pois, é a utilização sucessiva da mesma competência punitiva contra o infrator (...). A vedação do bis in idem, ... opera no nível de determinada esfera ou sistema sancionatório". OLIVEIRA, José Roberto Pimenta. Improbidade administrativa e sua autonomia constitucional. Belo Horizonte: Fórum, 2009, p. 230. 
Regina da Costa ${ }^{28}$. Denilson Marcondes Venâncio, que também parece compor o segundo grupo, traz uma interessante classificação entre limites internos e externos impostos pela VBI:

“No âmbito interno, no exercício das mesmas competências administrativa, civil e penal, a vedação da duplicidade de processo e decisão é absoluta. O esterno, interferências e reflexos da decisão de uma em outra, sendo a mais forte, juridicamente, a decisão do processo criminal". ${ }^{29}$

Na jurisprudência brasileira há um precedente antigo, mas importante para este trabalho, no qual o Superior Tribunal de Justiça (STJ) admitiu duas punições administrativas pelo mesmo fato, o que emprestaria à VBI um conteúdo bastante limitado. No caso, questionava-se multa por emissão abusiva de fumaça por veículo automotor lavrada por órgão ambiental, alegando que tal competência seria apenas do órgão de trânsito. O Tribunal considerou que:

"o fato, como acontecimento da experiência jurídica, enseja eventualmente, repercussão plural no Direito. Transitar com veículo, produzindo fumaça em níveis proibidos, interessa tanto ao Direito Ecológico como ao Direito da Circulação. Os respectivos objetos são diferentes. O primeiro busca conservar as condições razoáveis mínimas do ambiente. O segundo policia as condições de uso e funcionamento de veículos. Dessa forma, ainda que, fisicamente uno o fato, juridicamente, há pluralidade de ilícitos. Daí a legitimidade de o Departamento de Águas e Energia Elétrica, como do Detran, para aplicar sanções"30.

No caso concreto não houve uma dupla punição, mas o acórdão considerou essa possibilidade como admissível, dizendo que nesse caso "não haverá repetição de sanções, mas concurso de sanções, cada qual com seu pressuposto" ${ }^{31}$. Trata-se na verdade do conteúdo mais limitado que se possa emprestar à VBI, antes de - mas muito próximo a sua liquidação. Tão limitado que admite que o mesmo fato possa gerar duas sanções localizadas na mesma esfera ou sistema de apuração de responsabilidades (no caso, a do direito administrativo sancionador).

Um precedente mais recente seguiu uma linha próxima. Tratava-se de caso no qual empresa do setor de petróleo recebeu multa do órgão ambiental federal (IBAMA) e da

${ }^{28}$ COSTA, Helena Regina Lobo da. Direito Administrativo Sancionador e Direito Penal: a necessidade de desenvolvimento de uma política sancionadora integrada. In: BLAZECK, Luiz Mauricio Souza; MARZAGÃO JÚNIOR, Laerte I. (orgs.). Direito Administrativo Sancionador. São Paulo: Quartier Latin, 2014, pp. 115-116.

29 VENÂNCIO, Denilson Marcondes. Non Bis in idem e as Sanções Administrativas por Improbidade e Penal. Revista Trimestral de Direito Público, n. 61, p. 176, 2015. Dissemos que o autor "parece" estar no 2 - grupo pois, embora tenha uma versão mais protetiva da VBI, na conclusão do seu trabalho não ficou tão claro (e a falha pode ser nossa) qual exatamente a amplitude de proteção que o autor empresta à VBI.

30 RESP no. 4.608/90-SP, j em 19.09 .1990, Rel. Min Vivente Cernicchiaro, extrato da ementa.

31 Idem, p. 02 do voto do relator.

Revista Publicum

Rio de Janeiro, v. 6, n. 1, p. 13-41, 2020

http://www.e-publicacoes.uerj.br/index.php/publicum

DOI: $10.12957 /$ publicum.2020.57571 
entidade reguladora da indústria de petróleo (ANP) pelo mesmo fato: "rompimento de oleoduto com o respectivo vazamento de combustível". No entendimento do STJ:

"não prosperam as alegações de usurpação da competência dos órgãos do SISNAMA e da Capitania dos Portos e de violação ao princípio do non bis in idem. A referida multa não decorreu do dano ambiental em si, mas da inadequação da instalação do duto. A multa aplicada pelo IBAMA, ..., decorreu de lesão ao meio-ambiente. Já a multa imposta pela ANP adveio da operação e instalação, realizadas de modo tecnicamente inadequado. As sanções possuem natureza e fundamentos distintos. $E$ não há óbice para que a ANP penalize a autora, diante do acidente ocorrido. Ademais, ainda que não cause dano ambiental, qualquer operação ou instalação, no âmbito da indústria do petróleo, que não observe as normas técnicas representa infração administrativa, sujeita a penalidades"32.

Note-se que, nesse último caso, parece que era efetivamente possível separar duas realidades fáticas distintas (ainda que relacionadas): a operação da instalação de forma tecnicamente inadequada e o dano ambiental. Em sendo assim, realmente não haveria violação à VBI.

Há, no entanto, uma decisão do STJ em que se afirmou que "o postulado do non bis in idem representa uma vedação a uma dupla punição decorrente de uma mesma situação fática". Esta decisão poderia representar uma grande mudança em relação aos precedentes anteriormente citados, mas o fato é que, no caso concreto, o STJ afirmou que o sancionamento do agente estava ocorrendo por "condutas diversas" e no acórdão o tema não é desenvolvido ${ }^{33}$.

Também merece registro outro acórdão ${ }^{34}$, mais recente, em que o STJ analisou a situação de servidor da União que respondeu a Processo Administrativo-Disciplinar ("PAD"), no qual foi absolvido. Posteriormente, veio a ser condenado em processo criminal pelos mesmos fatos. Em decorrência da condenação penal, cuja sentença transitou em julgado, a Administração instaurou novo processo disciplinar que resultou na demissão do servidor. O STJ considerou procedente a "alegação de bis in idem, pois as infrações pelas quais o servidor foi condenado criminalmente e que seriam a base da demissão aplicada no" 2 PAD estavam compreendidas no objeto do PAD anterior, na qual ele havia sido absolvido. No caso a administração alegou que não haveria a violação do bis in idem pois o objeto do novo PAD não eram as irregularidades apuradas no processo anterior, mas a condenação penal transitada em julgado que the foi imputada. No entanto, como decidiu o STJ, o que se pune não é o fato do servidor ser condenado criminalmente, mas as condutas que levaram a essa condenação. O STJ, por outro lado, já

32 AgRg no AREsp 475.146/RJ, DJe 23/05/2014.

${ }^{33}$ AgInt nos EDcl no Agravo em Recurso Especial № 1.016.077 - ES.

${ }^{34}$ STJ, MS 17.994/DF, Primeira Seção, Rel. Min. Herman Benjamin, julg. 14.12.2016, DJe 17.04.2017.

Revista Publicum

Rio de Janeiro, v. 6, n. 1, p. 13-41, 2020

http://www.e-publicacoes.uerj.br/index.php/publicum

DOI: 10.12957/publicum.2020.57571 
admitiu um segundo processo em decorrência dos mesmos fatos quando o primeiro tiver sido anulado ${ }^{35}$.

Pois bem, este breve panorama da jurisprudência brasileira revela grande oscilação em relação ao conteúdo da $\mathrm{VBI}^{36}$ que, como visto, vai desde um conteúdo mínimo (que admite duas punições administrativas pelo mesmo fato desde que decorrentes de sistemas punitivos que protejam bens jurídicos distintos) até o entendimento que não admitiria duas punições pelos mesmos fatos.

\section{Um problema inesperado: o surgimento e crescimento de}

\section{novos esquemas punitivos}

A VBI não estava preparada nem para a grande expansão do direito administrativo sancionador, nem para o surgimento de outros regimes punitivos não enquadráveis nem no direito administrativo sancionador nem no direito criminal.

Com efeito, a VBI surge como princípio do direito penal, apenas porque o direito penal foi, por muito tempo, o único direito vocacionado à punição. Os problemas da VBI (a definição de seu conteúdo, o momento em que poderia ser invocado, etc.) eram problemas internos ao direito penal e processual penal (relacionados em especial ao concurso de ilícitos e à coisa julgada), que continuou, provavelmente até o final da $2 \underline{a}$ guerra, como o único sistema punitivo relevante na maioria dos países. Por estar inserido dentro do direito penal a VBI tinha como resultado limitar a punição a apenas uma, ainda que se discuta se essa única punição é pelo mesmo fato ou pelo mesmo crime (discussão que, como dissemos, é resolvida com a teoria do concurso de ilícitos).

Esta realidade mudou em diversos países com o enorme crescimento da atividade sancionatória por parte da administração pública que, em geral, acompanhou o aumento das atribuições do Estado a partir da década posterior ao fim da 2a guerra mundial. No Brasil, além deste crescimento da atividade sancionatória por parte da administração (que

35 “A aplicação de penalidade de demissão em novo procedimento administrativo não representa bis in idem em relação a anterior processo disciplinar anulado, no qual havia sido cominada pena menos gravosa, porquanto a anulação da primeira punição faz subsistir apenas uma penalidade para a conduta do servidor" (STJ, MS 13.640/DF, Terceira Seção, Rel. Min. Felix Fischer, julg. 15.12.2008, DJe 13.02.2009). Neste breve registro sobre a jurisprudência em torno da VBI vale registrar duas antigas Súmulas do Supremo Tribunal Federal: "18 Pela falta residual, não compreendida na absolvição pelo juízo criminal, é admissível a punição administrativa do servidor público" e "19 É inadmissível segunda punição de servidor público, baseada no mesmo processo em que se fundou a primeira".

${ }^{36}$ A mesma indefinição, se isso serve de consolo, ocorre no campo internacional, como anotado em CRYER, Robert, FRIMAN, Håkan, ROBINSON, Darryl, WILMSHURST, Elizabeth. An Introduction to International Criminal Law ... Op. cit, p. 86.

Revista Publicum

Rio de Janeiro, v. 6, n. 1, p. 13-41, 2020

http://www.e-publicacoes.uerj.br/index.php/publicum

DOI: 10.12957/publicum.2020.57571 
ganha velocidade e intensidade a partir dos anos 90 do século passado) surgem novos esquemas punitivos que dificilmente se enquadram no direito administrativo sancionador, em especial o sistema de apuração de responsabilidades com base na Lei de Improbidade Administrativa, sistema não penal mas indubitavelmente punitivo (embora também tenha um componente ressarcitório $)^{37}$. Mais recentemente temos um novo sistema trazido pela denominada Lei Anticorrupção.

Isto trouxe, em primeiro lugar, a necessidade de requalificar o antigo problema da relação entre o direito administrativo sancionador e o direito penal ${ }^{38}$, que, na verdade, se transformou (no Brasil), no problema da relação entre, de um lado, o mesmo direito administrativo sancionador, agora acompanhado de uma série de outros sistemas que podemos chamar de punitivos não penais e, de outro lado, o mesmo direito penal.

Além disso, surge um problema realmente novo, que é o da relação entre todos estes distintos sistemas punitivos não penais. Note-se que já se identificaram (em texto anterior à sanção da Lei anticorrupção) 9 distintos sistemas de responsabilização ${ }^{39}$, sendo que ao menos 7 deles seriam punitivos não penais ${ }^{40}$.

$37 \mathrm{Na}$ verdade, existe um enorme debate doutrinário acerca da qualificação da responsabilidade apurada com base na Lei de Improbidade administrativa. Fala-se em ilícito de natureza civil (DI PIETRO, Maria Sylvia Zanella. Direito administrativo. 26 ed. São Paulo: Atlas, 2013, p. 892-893 e GARCIA, Emerson, ALVES, Rogério Pacheco. Improbidade administrativa. 7 ed., 2 a tiragem. São Paulo: Saraiva, 2014, p. 590), responsabilidade administrativa (OSÓRIO, Fabio Medina. Teoria da Improbidade administrativa. São Paulo: RT, 2007, p. 234), quase-penal (linha seguida por Gilmar Ferreira Mendes, por ex na Recl. n. 4810/RJ, DJ 01/02/2007 PP-00135), ou, como preferimos, em linha próxima àquela desenvolvida por Pimenta de Oliveira, em uma nova forma de responsabilidade não reconduzível às demais (OLIVEIRA, José Roberto Pimenta. Improbidade administrativa... Op. cit., p. 88-89).

38 O problema da relação entre o direito penal e o direito administrativo sancionador não é novo, o que é (relativamente) novo é a enorme expansão deste último (expansão que inclui o aumento de áreas a ele sujeitas e um grande aumento da gravidade das penas, em especial do valor das multas administrativas).

${ }^{39}$ Com efeito, a partir dos quatro elementos que reputa estruturais para a construção dogmática de distintos sistemas de responsabilização (a configuração do ilícito, a delimitação das consequências jurídicas, a especificação dos bens jurídicos protegidos e o processo aplicável), José Roberto Pimenta Oliveira chega ao número impressionante de nove distintos sistemas de responsabilização albergados pela Constituição Brasileira e que constituiriam o "sistema constitucional de responsabilidade dos agentes públicos". Em primeiro lugar o autor lista cinco sistemas de responsabilização "aplicáveis a quaisquer agentes públicos, donde o rótulo de esferas gerais autônomas de responsabilidade dos agentes públicos: (1) a responsabilidade por ilícito civil (art. 36§6ㅇ)", de cunho reparatório; “(2) a responsabilidade por ilícito penal comum (art. 22, 1); (3) a responsabilidade por ilícito eleitoral (art. 14 e 22, 1); (4) a responsabilidade por irregularidade de contas (art. 71, VIII); (5) a responsabilidade por ato de improbidade administrativa (art. 37, § 40)". As duas últimas com caráter punitivo e reparatório. Além disso, o autor lista três "esferas especiais autônomas de responsabilidade dos agentes públicos" "restringidas a determinados agentes ou categorias de agentes públicos", a saber: "(6) a responsabilidade político constitucional, consubstanciada na previsão de crimes de responsabilidade"; "(7) a responsabilidade políticolegislativa, consistente na decretação da perda do mandato parlamentar, pelas infrações previstas no artigo 55; (8) a responsabilidade administrativa, incidente, excluídos os cargos políticos, sobre todos os titulares de cargo, função e emprego público". Finalmente, o autor identifica a existência 
O surgimento destes novos esquemas punitivos foi acompanhado de dúvidas significativas acerca de seus regimes jurídicos. Com alguma hesitação chegou-se a certo consenso de que todo sistema punitivo deve ser operado com o respeito aos princípios originalmente concebidos para o processo e o direito penal ${ }^{41}$ - incluído a VBI - embora a

de uma "esfera geral de responsabilidade dos agentes públicos, não autônoma, derivada da: (9) responsabilidade pela prática de discriminação atentatória dos direitos e liberdades fundamentais". OLIVEIRA, José Roberto Pimenta. Improbidade administrativa... Op. cit., p. 85-86; 91-141, grifos no original. Note-se que o autor admite amplamente a sobreposição de sanções oriundas de cada um destes sistemas sobre os mesmos fatos, por exemplo admitindo a cumulação de sanções aplicadas pelo Tribunal de Contas da União com base na Lei 8.433/92 com "sanções de mesma índole", inseridas na Lei de Improbidade Administrativa (Idem, p. 462).

40 Não concordamos com o autor no sentido de que todos os sistemas de que ele trata sejam efetivamente distintos quanto à sua natureza jurídica, mas não há dúvidas de que eles existem e que a possibilidade de sobreposição de sanções é grande, como se verá mais à frente

${ }^{41}$ Esta é a posição das cortes internacionais de direitos humanos como veremos adiante. Sobre o tema vide o pioneiro trabalho de MOREIRA NETO, Diogo de Figueiredo e GARCIA, Flavio Amaral. A principiologia no direito administrativo sancionador. Revista Brasileira de Direito Público RBDP, Belo Horizonte, ano 11, n. 43 out/dez 2013. Pimenta Oliveira também fornece um enquadramento teórico muito bem fundamentado antes de enunciar os princípios aplicáveis a qualquer atividade punitiva estatal: "não há como desconsiderar os elementos axiológicos e normativos comuns, tirados das normas constitucionais que, ..., fornecem substancial identidade capaz de justificar a existência de uma categoria jurídica geral e própria, a reunir ..., a diversidade de pretensões punitivas estatais, previstas no ordenamento constitucional, na defesa de variada tipologia de bens jurídicos essenciais à vida social.

A admissão de regime punitivo estatal fundado na principiologia constitucional informativa do exercício desde tipo de atividade, independentemente do âmbito material referido, não diminui nem fragiliza a existência - sob o império constitucional dos vetores basilares daquele regime - de outros regimes derivados, dentre os quais sobressai o regime jurídico-administrativo sancionador. É relevante frisar que a atividade punitiva do Estado não se esgota ao plano do direito penal e do recentemente rotulado direito administrativo sancionador.

Em sua unidade, todos os princípios limitativos do poder punitivo estatal são reconduzíveis ao princípio matriz do Estado de Direito (art. 10, caput, CF). Se, de um lado, o nosso ordenamento impõe, por exigência da República, uma rigorosa arquitetura constitucional para reprimir a improbidade na vida pública, o mesmo Direito Constitucional, de outro lado, impõe rigorosas limitações materiais e formais ao exercício do dever-poder punitivo.

(...) a interpretação sistemática da Constituição sinaliza para existência de princípios constitucionais comuns que governam qualquer atividade estatal punitiva, com as adequações valorativas necessárias de cada campo material sobre o qual incidem. Nesta linha, é cabível sustentar a existência de um regime jurídico punitivo, com esteio na vertente normativa do Estado de Direito. (...)

Este plexo normativo fundamental limita a imposição de sanções estatais, seja pela Administração Pública, seja pelo Poder Legislativo, seja pelo Poder judiciário. Logo, serve de firme contenção à arbitrariedade na criação, regulação, tipificação e sancionamento de atos ímprobos. (...)

Apesar de não reconhecido este regime punitivo estatal na linguagem constitucional, é possível construir sua moldura a partir de diversos princípios e regras constitucionais, nas quais impera muitas vezes a invocação da matéria penal. Há, à toda evidência, o fato histórico-social significativo de que o direito penal nas sociedades ocidentais, desde as injunções do iluminismo, Liberalismo e Individualismo, já atingiu relevante estágio de desenvolvimento teórico. Daí que o conteúdo constitucional da principiologia maior faça constante referência ao jus puniendi na área criminal. Inobstante, a similitude da razão jurídica das limitações impostas ao jus puniendi criminal autoriza, com a cuidadosa tarefa de absorção dos valores fundamentais em sua devida latitude, a extensão das garantias para outros domínios punitivos, levando em consideração o dever do intérprete em adequá-los ao contexto de regulação da conduta viciada objeto de reprimenda". OLIVEIRA, José Roberto Pimenta. Improbidade administrativa... Op. cit., p. 200-201, grifos no original.

Revista Publicum

Rio de Janeiro, v. 6, n. 1, p. 13-41, 2020

http://www.e-publicacoes.uerj.br/index.php/publicum

DOI: 10.12957/publicum.2020.57571 
intensidade com que tais princípios devem ser aplicados a cada um destes sistemas é objeto de enorme dissenso.

Mas o que nos preocupa neste trabalho é o papel da VBI na relação entre todos estes - agora diversos - sistemas não penais. Lembre-se que, antigamente, a eventual admissão de que a VBI era compatível com uma punição penal e outra administrativa resultava na possibilidade de duas punições pelo mesmo fato. Pois bem, seria possível conceber uma VBI que admitisse tantas punições quantos fossem os distintos sistemas punitivos possivelmente incidentes sobre determinado fato?

Ou seja, será que, em um país que tenha quatro sistemas punitivos possivelmente incidentes sobre um fato, o máximo que se retira da VBI é proibir a quinta punição? A tentação de admitir uma tal solução era - e permanece sendo - alta porque a multiplicação de sistemas punitivos tem como uma de suas razões a necessidade de proteger bens jurídicos ultrassensíveis, tema ao qual nos dedicaremos a seguir.

\section{Um problema ampliado: a sobreposição de esquemas de responsabilização de bens jurídicos supersensíveis}

No final do século XX e início do século XXI a proteção de certos bens jurídicos passa a ganhar um destaque especial, seja pela sensibilidade em si do bem seja pela dificuldade em protegê-lo com os esquemas tradicionais de responsabilização, seja por ambas razões.

Podemos incluir dentre tais bens a vida e a segurança (ameaçada pela violência, em especial do terrorismo), a moralidade administrativa (ameaçada pela corrupção política cada vez mais levada ao conhecimento da população ${ }^{42}$ ) e o meio ambiente (ameaçado por distintas formas).

Em geral, percebeu-se que os esquemas tradicionais de responsabilização, por distintas razões, não protegiam adequadamente tais bens. Assim, em matéria de combate

\footnotetext{
42 Para os que, no Brasil, acreditam que a corrupção é um mal quase que especificamente brasileiro, lembremos que Tony Judt, em sua monumental obra sobre a Europa no Pós-Guerra, afirma, tratando dos anos 90, que "quase universalmente, os principais partidos políticos da Europa Ocidental" começaram a "buscar meios alternativos de captar fundos". (...). "Na França, ficou comprovado que gaullistas e socialistas - a exemplo dos Democratas Cristão, na Alemanha, e do Novo Trabalhismo, na Grã-Bretanha - haviam conseguido recursos ao longo das últimas duas décadas de várias maneiras escusas: vendendo favores, traficando influência ou, simplesmente, apoiando-se mais insistentemente do que nunca em doadores tradicionais". A situação foi um pouco mais longe na Bélgica". Judt cita ainda o caso da Itália, "onde, desde a guerra, os democratas cristãos gozavam de uma relação amigável e lucrativa com banqueiros, empresários, empreiteiros, chefões municipais, funcionários públicos e - segundo muitos boatos, com a Máfia", e da Espanha. JUDT, Tony. Pós-Guerra Uma História da Europa desde 1945. Rio de Janeiro: Objetiva, 2007, p. 734735. Sobre a França veja-se LASCOUMES, Pierre (org.). Favoritisme et Corruption à la française. Petits arrangements avec la probité. Paris: Presses de Sciences Po, 2010.
} 
ao terrorismo indicou-se que diversos direitos individuais, inclusive protetores da intimidade, seriam obstáculos a serem $\operatorname{superados}^{43}$. Em matéria ambiental a dificuldade em identificar e segmentar condutas causadoras de danos de grande extensão foi recomendando esquemas de imputação solidária de responsabilidade e de inversão de certas presunções processuais. Em relação à corrupção, da mesma forma, houve uma percepção de que seu combate pelo direito penal não era efetivo ${ }^{44}$.

Em reação a estas dificuldades foram criados novos sistemas de responsabilização, foram feitas alterações importantes em alguns deles e, o que mais nos interessa aqui, tais bens jurídicos especialmente sensíveis passaram a ser objeto de tutela por distintos e sobrepostos esquemas de responsabilidade.

Ou seja, tais bens passaram a ser protegidos ao mesmo tempo por distintos sistemas de responsabilização punitivos (como o penal e o administrativo sancionador), reparatórios (como o da responsabilidade civil) e por sistemas "híbridos", que cumulam consequências punitivas e reparatórias (como é o caso da Lei de Improbidade, da Lei anticorrupção e do sistema de apuração de responsabilidade perante os tribunais de contas), cada um com características próprias. Assim, por exemplo, em relação a certas condutas ilícitas praticadas por agentes políticos, é possível, em tese (e desconsiderando a

43 Para um histórico do tema nos Estados Unidos, incluindo a aprovação do polêmico "Patriot Act", vide LIZZA, Ryan. Secrets, lies, and the N.S.A. The New Yorker, 16 dez 2013, p. 48-61. Vide ainda: GOLDSTONE, Richard. The tension between Combating Terrorism and Protecting Civil Liberties. In: WILSON, Richard Ashby (ed.). Human Rights in the 'War on Terror'. Cambridge: Cambridge University Press, 2005. Mas a questão não se limita aos Estados Unidos. Na França, após os terríveis atentados de novembro de 2015 alguns direitos fundamentais também foram restringidos. Na América Latina vale citar a decisão da Corte Interamericana de Direitos Humanos no caso Loayza Tamayo vs. Peru (sentença de 17 de setembro de 1997) em que aspectos da legislação peruana adotada como forma de combate aos atos do grupo terrorista "Sendero Luminoso" foram apreciados. A Corte, na ocasião, registrou ( $\$ 44$ da sentença) que:

"Al valorar estas pruebas la Corte toma nota de lo señalado por el Estado en cuanto al terrorismo, el que conduce a una escalada de violencia en detrimento de los derechos humanos. La Corte advierte, sin embargo, que no se pueden invocar circunstancias excepcionales en menoscabo de los derechos humanos. Ninguna disposición de la Convención Americana ha de interpretarse en el sentido de permitir, sea a los Estados Partes, sea a cualquier grupo o persona, suprimir el goce o ejercicio de los derechos consagrados, o limitarlos, en mayor medida que la prevista en ella (artículo 29.2). Dicho precepto tiene raíces en la propia Declaración Universal de Derechos Humanos de 1948 (artículo 30)".

44 No Brasil isto é muito claro em meados da década dos 1990, quando se colocou enorme expectativa no sucesso da então recente lei de improbidade administrativa, sobretudo após grandes operações de combate à corrupção terem sido anuladas por questões processuais. No entanto, ao final, foi o direito penal, auxiliado por novos instrumentos dentre os quais se destaca a delação (ou colaboração) premiada, que acabou sendo responsável pelo relativo sucesso de grandes operações de combate à corrupção no Brasil (incluindo a polêmica "Operação Lava Jato"), ainda que tenham ocorrido excessos e desvios preocupantes, incluindo a possível escolha de prioridades por razões mais políticas do que jurídicas. Sobre o mais polêmico instrumento da "Lava Jato", vide CANOTILHO, J. J. Gomes; BRANDÃO, Nuno. Colaboração premiada e auxílio judiciário em matéria penal: a ordem pública como obstáculo à cooperação com a operação Lava Jato. Revista de Legislação e de Jurisprudência, ano 146ำ n. 4000, set-out 2016. 
VBI), que delas resulte uma: (a) sanção jurídico-política (condenação por crime de responsabilidade com afastamento do cargo); (b) uma sanção aplicada por meio da Lei de Improbidade; (c) uma sanção aplicada por um Tribunal de Contas e (d) uma sanção criminal (se o fato também constituir crime comum) e tudo isto sem prejuízo da (e) obrigação de reparar o dano 45 .

No entanto, se a proteção de um bem jurídico por distintos sistemas de responsabilização não é em si uma novidade - nem tampouco algo negativo - é certa a necessidade de que cada um destes sistemas observe as regras e princípios que lhe são próprios $^{46}$. Ou seja, a união de sistemas para proteger um mesmo bem não pode significar a perda de identidade de cada um desses sistemas.

Por exemplo, vários bens jurídicos são protegidos ao mesmo tempo por mais de um ramo ou sub-ramo do direito e também são objeto de tutela penal ${ }^{47}$. $E$, em qualquer destes casos, instaurada uma persecução criminal ou administrativa, ela passa a estar submetida ao conjunto de normas que limitam e informam a atuação punitiva estatal qualquer que ela seja, administrativa, penal ou de outra natureza - em especial o devido processo legal, a segurança jurídica, a legalidade, a tipicidade, e a VBI.

No entanto, na tutela punitiva destes bens especialmente protegidos (aí incluída a tutela da moralidade pública) é cada vez mais comum a invocação de princípios, teorias e doutrinas que surgiram - e, ao menos em princípio, devem permanecer - na esfera

\footnotetext{
45 Que pode ser apurada na mesma ação de improbidade administrativa ou mediante uma grande variedade de outras ações com distintos titulares (por exemplo, ação civil pública e ação popular).

${ }^{46} \mathrm{Um}$ exemplo importante no sentido de que determinada característica pode ser adequada a um sistema de responsabilização e insustentável em outro sistema se refere às teorias da causalidade. Assim, como observado por Anderson Schreiber:

"A teoria da equivalência das condições encontrou acolhida na seara do direito penal, justificadamente. Ali, o princípio da tipicidade limita o âmbito de extensão da conditio sine qua non, restringindo o juízo de responsabilização sobre as condutas típicas praticadas, ainda que outras tenham concorrido e, portanto, se afigurem, em tese, como causas do resultado punível. Por exemplo, a conduta do vendedor de material esportivo pode ser considerada causa, porque conditio sine qua non, do dano provocado por uma bola de golfe que vendera a um jogador, o qual, deliberadamente ou por infortúnio, vem a acertar, durante a partida, um passante. Já não pode, todavia, ser o vendedor considerado penalmente responsável por falta de tipicidade da sua conduta, que, sendo lícita, não se encaixa em qualquer tipo descrito na codificação criminal. O mesmo não aconteceria na esfera cível, onde a atipicidade do ato ilícito resultaria em responsabilização do comerciante, efeito claramente indesejável por sua sonora injustiça.

Em outras palavras, os efeitos expansionistas da teoria da equivalência das condições não se verificam no direito penal, mas poderiam ser destrutivos no direito civil, onde a responsabilidade se guia por cláusulas gerais, sem a amarra de um princípio de tipicidade, característico do campo criminal, onde a responsabilidade tem finalidade punitiva e objeto limitado às ofensas de interesse público". SCHREIBER, Anderson. Novos Paradigmas da Responsabilidade Civil. 6 ed. São Paulo: Atlas, 2015, p. 57. Esta circulação de teorias da causalidade é um risco sério quando pensamos na existência de sistemas punitivos com tipos tão abertos quanto os da improbidade administrativa.

47 Podemos pensar no direito da concorrência, no direito administrativo econômico, ou mesmo no direito tributário todos também objeto de alguma tutela penal.
} 
reparatória, ao mesmo tempo em que se diluem ou "ponderam" os direitos e garantias relacionados à atuação persecutória do estado ${ }^{48}$, inclusive, e talvez especialmente, a VBI.

Não negamos a possibilidade, que pode até ser positiva, de um fluxo de institutos, técnicas, regras ou princípios entre distintos ramos do direito. Na verdade, a História do direito está cheia de exemplos nesse sentido. O que condenamos, e de forma veemente, é que este fluxo seja feito de maneira completamente acrítica e casuística sem qualquer consideração seja quanto às características do ramo do direito de onde saiu o instituto, do ramo que o receberia e das consequências da importação.

O problema é que, numa releitura velada da afirmação de que "os fins justificam os meios" acontecem dois fenômenos interligados: Em primeiro lugar a "ponderação" (melhor seria dizer a liquefação) dos direitos de quem está em posição "contrária" ao bem jurídico ultra sensível (ex. direitos à intimidade na luta contra o terrorismo, a indisponibilidade e a desnecessidade de imputação na ação de improbidade). Em segundo lugar a circulação irrefletida (para não dizer leviana) de instrumentos e institutos de um sistema para o outro (como a aplicação generalizada e nada técnica do princípio da precaução $\left.{ }^{49}\right)$.

Vejamos como isso se deu no que se refere à VBI.

Como dissemos, não existem normas expressas afirmando a VBI no direito interno brasileiro. Uma exceção indireta é o artigo 935 do Código Civil ${ }^{50}$ que tem sido lido como impedindo qualquer outro processo (reparatório ou sancionatório) quando a sentença

48 Por exemplo, numa ação de improbidade administrativa, o Tribunal Regional Federal da 2a Região entendeu que: "basta que o Ministério Público descreva as condutas (...) e requeira, ainda que genericamente, a condenação com base no art. 12 da Lei de Improbidade para que o juízo subsuma os fatos às condutas previstas nos arts 9o, 10 e 11 e aplique as sanções que reputar cabiveis previstas nos incisos do art. 12, com base na parêmia "da mihi factum, dabo tibi ius" ("dá-me o fato que te darei o direito"). Não há nisso violação da ampla defesa e do devido processo legal, dado que o réu se defende de fatos a si imputados, e não desta ou daquela capitulação legal presente na Lei 8.429/92". (Agravo n. 0006182-53.2013.4.02.0000 (201302010061826), DJ 10.07.2014). Ou seja, no entendimento do referido Tribunal uma pessoa pode ser submetida a processo punitivo (inclusive ter os bens bloqueados cautelarmente) sem que o Estado-acusação sequer tenha que informar qual ilícito entende que foi cometido. Note-se que o artigo 8o "2" " 4 " da Convenção da Costa Rica garante o direito à "comunicação prévia e pormenorizada ao acusado da acusação formulada". A violação flagrante deste direito fundamental (ser informado do que está sendo acusado) é, a nosso ver, mais um chocante exemplo (além daquele objeto deste trabalho) de como, no Brasil, as supostas boas intenções (os fins, como "combater a improbidade" parecem justificar os meios (ignorar ou "relativizar" qualquer direito que se oponha à finalidade desejada).

${ }^{49}$ Segundo o STJ "O princípio da precaução pressupõe a inversão do ônus probatório, competindo a quem supostamente promoveu o dano ambiental comprovar que não o causou ou que a substância lançada ao meio ambiente não lhe é potencialmente lesiva" (Resp 1.060.753-SP) O problema é que o caso tratava de multa administrativa, ou seja, de processo punitivo.

50 Art. 935. A responsabilidade civil é independente da criminal, não se podendo questionar mais sobre a existência do fato, ou sobre quem seja o seu autor, quando estas questões se acharem decididas no juízo criminal. 
criminal (prolatada com base nos incisos I ou IV do artigo 386 do Código de Processo Penal) reconhecer a inexistência do fato ou que o réu não concorreu para a infração ${ }^{51}$.

No entanto, existem normas expressas fazendo exatamente o contrário, ou seja, afastando a VBI. Duas destas normas se encontram no próprio texto da Constituição Brasileira.

A primeira é o artigo $225 \S 3$ 으 da Constituição Federal, segundo o qual as "condutas e atividades consideradas lesivas ao meio ambiente sujeitarão os infratores, pessoas físicas ou jurídicas, a sanções penais e administrativas, independentemente da obrigação de reparar os danos causados". Assim, pelo teor de tal dispositivo, é clara a possibilidade de que a mesma conduta gere duas consequências punitivas (uma criminal e uma administrativa) cumulada com uma obrigação de reparar o dano.

A segunda é o $\S$ 4ㅇ do artigo 37, segundo o qual: “Os atos de improbidade administrativa importarão a suspensão dos direitos políticos, a perda da função pública, a indisponibilidade dos bens e o ressarcimento ao erário, na forma e gradação previstas em lei, sem prejuízo da ação penal cabível"52. Ou seja, por este dispositivo os atos de improbidade podem resultar em certas sanções (que posteriormente foram reguladas pela Lei de Improbidade administrativa), cumuladas com o ressarcimento e com a possibilidade da sanção penal.

Até aqui estamos em hipótese em geral aceita em distintos ordenamentos (a situação mudou em relação aos países vinculados à convenção europeia de direitos humanos, como veremos mais à frente), ou seja, a cumulação de uma punição de natureza penal com outra de natureza não penal acompanhada da obrigação (não punitiva), de reparar os danos.

Outra lei que afasta a VBI é a denominada Lei de abuso de autoridade (Lei 13.869/19), segundo a qual as penas nela previstas "serão aplicadas independentemente das sanções de natureza civil ou administrativa cabíveis" (art. 6o da Lei). A mesma Lei (art. 70) proclama que "as responsabilidades civil e administrativa são independentes da

51 Esta é a posição, por exemplo, de Denilson Venâncio que expressamente defende que tal dispositivo alcança a improbidade administrativa (que este autor considera ter natureza civil); VENÂNCIO, Denilson Marcondes. Non Bis in idem... Op. cit., p. 176. No entanto, como lembra o mesmo autor, remanesce a possível aplicação da Súmula 18 do STF, segundo a qual "Pela falta residual, não compreendida na absolvição pelo juízo criminal, é admissível a punição administrativa do servidor público". Este autor também cita o Art. 65 do CPP, segundo o qual: "Faz coisa julgada no cível a sentença penal que reconhecer ter sido o ato praticado em estado de necessidade, em legítima defesa, em estrito cumprimento de dever legal ou no exercício regular de direito".

52 Dispositivo que foi incorporado no artigo 12 da Lei de Improbidade Administrativa. 
criminal, não se podendo mais questionar sobre a existência ou a autoria do fato quando essas questões tenham sido decididas no juízo criminal" ${ }^{25}$.

Mais um exemplo importante é a Lei 9.504/97, conhecida como "lei Eleitoral". Seu artigo 73 traz uma longa lista de "condutas tendentes a afetar a igualdade de oportunidades entre candidatos nos pleitos eleitorais" e que por isso "são proibidas aos agentes públicos". Trata-se, portanto, de uma lista de "ilícitos eleitorais". Os §§ 4ㅇ a 6ㅇ do mesmo dispositivo trazem as sanções que podem ser aplicadas pela prática de tais ilícitos, incluindo multa e cassação do registro ou do diploma eleitoral. Não satisfeito, o § 70 (do mesmo artigo 73), estabelece que "as condutas enumeradas no caput caracterizam, ainda, atos de improbidade administrativa", a que se refere o art. 11, I da Lei 8.429/92, e sujeitam-se às disposições daquele diploma legal, em especial às cominações do art. 12, inciso III". Finalmente, o artigo 78 da mesma Lei Eleitoral estabelece que a "a aplicação das sanções cominadas no art. 73, §§ 4ㅇe e 5ㅇ, dar-se-á sem prejuízo de outras de caráter constitucional, administrativo ou disciplinar fixadas pelas demais leis vigentes" 54.

Mas o dispositivo realmente "draconiano" em matéria de afastamento de VBI é o artigo 30 da Lei anticorrupção. Trata-se de lei instituidora de sistema de responsabilização que, tal como o de improbidade, cumula consequências punitivas (bastante sérias) com consequências reparatórias, tendo como foco a punição de pessoas jurídicas. Pois bem, segundo o referido dispositivo, a "aplicação das sanções previstas" na Lei anticorrupção "não afeta os processos de responsabilização e aplicação de penalidades decorrentes de "ato de improbidade administrativa nos termos da Lei ${ }^{\circ} 8.429$ " nem os de "atos ilícitos

53 Também estabelece (art. $8^{\circ}$ ) que "Faz coisa julgada em âmbito cível, assim como no administrativo-disciplinar, a sentença penal que reconhecer ter sido o ato praticado em estado de necessidade, em legítima defesa, em estrito cumprimento de dever legal ou no exercício regular de direito".

54 Pimenta Oliveira, por exemplo, não vê nenhuma violação à VBI na hipótese, afirmando que o artigo 78: "retira qualquer dúvida sobre a positivação de esfera distinta de responsabilidade funcional, como consequência jurídica desfavorável imposta pelo poder punitivo estatal atrelado à condição funcional de agente público atuando em desrespeito à legalidade, com feitio singular. Face a determinada conduta funcional ilícita, a cumulatividade é o distintivo maior da autonomia do sistema legal.

A aplicação de multa eleitoral pela Justiça Eleitoral não exime o agente público de sofrer a penalidade de multa civil aplicada pela jurisdição civil comum, nos termos da Lei n 8.429/92. (...) haverá, no máximo, repercussão no momento da fixação in concreto do quantum imposto ao agente público, pela prática dos mesmos fatos, em atenção ao princípio da proporcionalidade.

Confirma-se, pois, um dado normativo irrefutável: não é a presencialidade na disciplina legal de certa sanção com o mesmo conteúdo (v.g. multa punitiva) que desqualifica instâncias sancionatórias, com base na alegação do bis in idem. Na comparação aqui feita, não há exercício de mesma competência punitiva, porque diversa é a compostura jurídica de cada qual. E, logo, não há bis in idem inconstitucional em cenário que resulta no duplo sancionamento do mesmo agente, por multa, no campo eleitoral e no campo da improbidade". OLIVEIRA, José Roberto Pimenta. Improbidade administrativa... Op. cit., p. 487 e ss., grifos no original. 
alcançados pela Lei $\mathrm{n}^{\circ} 8.666$, de 21 de junho de 1993 , ou outras normas de licitações e contratos da administração pública".

Note-se que alguns tipos infracionais da lei anticorrupção são muito parecidos ou mesmo idênticos aos da lei de improbidade e aos da lei de licitações. Tome-se como exemplo os dispositivos dirigidos à punição da fraude em licitações. Tal conduta é punida pela Lei anticorrupção ${ }^{55}$, pela Lei de Improbidade Administrativa ${ }^{56}$ e pela parte penal da Lei $8.666 / 93^{57}$. Além disso, tal conduta em geral será passível de punição com base no direito administrativo sancionador (por exemplo com base em normas do próprio edital da licitação).

Assim, o artigo 30 da Lei n. 12.846/13 permitiria que alguém seja punido não duas, mas três ou até quatro vezes, pelo mesmo fato (e por hipóteses de incidência quase idênticas), por três ou quatro sistemas punitivos distintos (penal, improbidade administrativa, Lei Anticorrupção e direito administrativo sancionador) $)^{58}$.

Ora, considerando ser evidente que todos os referidos dispositivos protegem exatamente o mesmo bem jurídico: a lisura das licitações; devemos indagar se é possível, de forma compatível com a VBI, punir alguém pelo mesmo fato na esfera criminal e com base em dois (ou mais) sistemas punitivos não penais. A resposta evidentemente é negativa.

A festejada (não exatamente por este ponto) alteração que a Lei 13.655/18 trouxe à Lei de Introdução às normas do direito Brasileiro "LINDB"59 (no que se refere às normas de direito público), trouxe uma tentativa tão tímida de resgate da VBI que, na verdade, acaba por negá-lo à montante para emprestar-lhe conteúdo mínimo à jusante. Trata-se do § 3 ㅇ do artigo 22 da referida lei que estabelece que "as sanções aplicadas ao agente serão levadas em conta na dosimetria das demais sanções de mesma natureza e relativas ao mesmo fato". Ou seja, tal dispositivo parece permitir uma múltipla sobreposição de punições, uma vez que a circunstância de alguém ter sido sancionado por determinado fato não o impede nem de ser processado nem de ser sancionado novamente pelo mesmo fato, contentando-se apenas em que as sanções anteriormente aplicadas sejam "levadas

${ }^{55}$ Art. 5ㅇ, IV “Constituem atos lesivos à administração pública ... no tocante a licitações e contratos: a) frustrar ou fraudar, mediante ajuste, combinação ou qualquer outro expediente, o caráter competitivo de procedimento licitatório público; (...) d) fraudar licitação pública ou contrato dela decorrente;"

${ }^{56}$ Art. 10, VIII. "Constitui ato de improbidade administrativa (...) frustrar a licitude de processo licitatório ou dispensá-lo indevidamente;"

57 "Dos crimes". "art. 96, Fraudar, em prejuízo da Fazenda Pública, licitação instaurada para aquisição ou venda de bens ou mercadorias, ou contrato dela decorrente".

58 O que faz lembrar o "cara ou coroa" referido acima (nota 15), na qual o Estado-acusador diz ao acusado: "se der cara nós ganhamos, se der coroa jogaremos novamente até você perder".

59 Decreto-Lei no 4.657, de 4 de setembro de 1942. 
em conta na dosimetria das demais sanções". Difícil conceber conteúdo mais reduzido à $\left.\mathrm{VB}\right|^{60}$.

Lembre-se de que o exemplo acima (relativo às licitações) é apenas um dos diversos exemplos de fatos ou atos que podem ocasionar múltiplas e sobrepostas punições, todas destinadas a proteger $\circ$ que denominamos bens jurídicos "supersensíveis", bens jurídicos que, como dissemos, por sua qualidade intrínseca ou pela repercussão social dos ataques que receberam foram ao longo do tempo sendo objeto de múltiplos e sobrepostos esquemas de responsabilização.

Mas até onde é possível ir na tentativa de proteger bens jurídicos supersensíveis responsabilizando aqueles que o violam? A VBI é exatamente um desses limites, um limite que, por vezes, pode significar uma concessão que a virtude faz ao vício (o mesmo pode ser dito do direito de defesa "com os meios e recursos a ela inerentes" ...), mas que, ou é minimamente levado a sério, ou representará o desprezo a normas que tentam conter os excessos da atuação punitiva do estado desde meados do século XVIII e que foram, sucessivamente, sendo consagradas em textos constitucionais e em tratados internacionais.

O problema é que a extrema sensibilidade destes bens cria constrangimentos - no espaço público - para qualquer um que queira lembrar que sua tutela também tem

60 Com efeito, como bem reconhece Eduardo Jordão, a redação do dispositivo não proíbe $o$ bis in idem, com a sanção anterior impactando apenas o quantum da sanção posterior mas sem que aquela (primeira sanção) impeça a segunda. Embora cite outro autor (José Carlos Berardo) que, a nosso ver corretamente, reconhece que a redação acabou por legitimar o bis in idem, Jordão traz a seguinte interpretação - muito otimista mas certamente interessante - para o dispositivo (e que vai ao encontro de nosso entendimento de que a matéria é constitucional): "Sob uma perspectiva estritamente pragmática (que perpassa toda a lei), a luta contra o bis in idem não foi comprometida pela inserção deste artigo. É que os argumentos contrários ao bis in idem são de ordem constitucional. A ideia seria a de que sanções de mesma natureza, para o mesmo sujeito, pelo mesmo fato, violariam a Constituição. Esta batalha, portanto, pode continuar sendo travada. Caso vencida, implicaria a inconstitucionalidade do art. 22, §3‥ Enquanto esta batalha não esteja ganha, no entanto, o §3으 oferece um paliativo para as duplicações de sanções que já existem e que são realidade: a partir de agora, caso haja duplicação de sanções de mesma natureza, a segunda sanção deverá ser aplicada tendo-se em conta a primeira. (...)

De um ponto de vista de política legislativa, é possível que os autores da lei tenham antevisto uma esperada dificuldade para aprovar um enunciado que determinasse o fim do bis in idem. Trata-se de dispositivo hipotético que produziria uma enorme consequência institucional, limitando significativamente a competência das mais diversas entidades dotadas de poder sancionador. Seria sem dúvida uma das mais polêmicas previsões de um projeto de lei que já encontrou significativa resistência. Assim, é possível que tenha sido feita uma opção consciente por uma solução paliativa, ao invés de solução alguma. Nesta leitura, portanto, o artigo 22, oferece um atenuante para a situação atual, ao tempo em que não compromete a luta pelo reconhecimento da sua inconstitucionalidade". JORDÃO, Eduardo. Art. 22 da LINDB Acabou o romance: reforço do pragmatismo no direito público brasileiro. Revista de Direito Administrativo - RDA Edição Especial Direito Público na Lei de Introdução às Normas de Direito Brasileiro - LINDB (Lei no 13.655/2018), p. 63-92, nov. 2018, p. 87-89 (agradecemos ao colega Victor Aguiar por nos ter chamado a atenção quanto a esta interpretação). 
limites. Estes são, de forma açodada, chamados de poluidores, se apontam excessos no direito ambiental, de ingênuos ou amigos de terroristas, se apontam excessos do estado policial, e de defensores de corruptos, quando apontam excessos nas medidas de combate à corrupção governativa. A força destes bens sensíveis é tamanha que é possível assistir à defesa da inversão do ônus da prova em processos punitivos (posição já adotada pelo STJ em matéria de processos administrativos sancionatórios na área ambiental com base no princípio da precaução, como mencionado acima) ou a flexibilização do direito de defesa e da presunção de inocência, e, evidentemente, do esvaziamento quase integral da VBI.

Vale registrar que, ao criticar estes excessos, Denilson Venâncio lembra o fato (que sempre consideramos, mas pela primeira vez vemos por escrito), de que no Brasil "se gasta e se preocupa mais com fiscalização que com a execução propriamente dita, no exercício da função administrativa", aumentam "vertiginosamente as hipóteses normativas de crime e de improbidade, como se, assim, todos os males fossem solucionados"61. Na verdade, como já tem sido denunciado em várias esferas, os excessos punitivos no Brasil, especialmente aqueles dirigidos aos servidores públicos, tem causado uma paralisia da administração ${ }^{62}$, que inclui a paralisia de atividades indispensáveis para a prestação de direitos sociais (não há escolas nem hospitais sem atividade administrativa, sem licitação, sem contratos, e está cada vez mais difícil encontrar quem se responsabilize por tais atividades).

Mas este tratamento da VBI, a quem se presta homenagens retóricas ao mesmo tempo que se retira qualquer conteúdo efetivo em cada caso concreto (o mesmo tem acontecido com a separação de poderes) não tem sido seguida pelas Cortes internacionais em matéria de direitos humanos como veremos em seguida.

61 VENÂNCIO, Denilson Marcondes. Non Bis in idem... Op. Cit., p. 182. Com efeito, este tema extrapola o objeto deste trabalho, mas é impressionante - e merecia maior atenção da academia como se gasta no Brasil muito mais com instituições dedicadas a atividades "meio", em especial de fiscalização do que com instituições que devem prover tarefas finalísticas do Estado (saúde, educação, meio ambiente), inclusive aquelas destinadas a proteger os bens híper sensíveis.

62 Sobre o tema seja permitido fazer referência a nosso trabalho sobre o medo e o ato administrativo, disponível em http://www.direitodoestado.com.br/colunistas/rodrigo-tostesmascarenhas/o-medo-e-o-ato-administrativo bem como à recentíssima obra SANTOS, Rodrigo Valgas dos. Direito administrativo do medo. São Paulo: RT, 2020. 


\section{A VBI na jurisprudência internacional}

A Corte Europeia de Direitos do Homem, desde a decisão no caso Engel vs. Países Baixos, de 1976, reforçada no mais recente caso Sergey Zolotukhin vs. Rússia, ${ }^{63}$ de 2009, deixou claro que o fato da legislação de determinado país denominar um sistema punitivo como administrativo (ou não penal) não significa que os dispositivos da convenção referentes ao processo penal não possam ser aplicáveis, sempre que presentes certas características (denominadas de "Engel Criteria"), incluindo a classificação legal da ofensa, a sua natureza e a gravidade da pena imposta.

A Corte (p. 30 da decisão do Caso Engel) reconhecia, já em 1976, que todos os estados membros da convenção já havia muito tempo faziam uma distinção entre procedimentos disciplinares e criminais. E acrescentava que, tradicionalmente, para os indivíduos afetados, os sistemas disciplinares têm vantagens em relação aos criminais, em especial por terem penas mais brandas. No entanto, também ressalvava a Corte, processos criminais são normalmente acompanhados de maiores garantias.

Frente a esta situação, a Corte afirmava a necessidade de verificar se a classificação de uma infração (criminal ou administrativa) feita pelo Direito nacional era decisiva. Indagava se determinado artigo da Convenção (art. 6, expressamente direcionado a processos criminais) deixaria de ser aplicável porque um estado denomina um ato ou omissão como um ilícito disciplinar. E, de forma que diretamente nos interessa, a Corte salientava que este problema era particularmente importante "quando um ato ou omissão é tratado pelo Direito doméstico ... como um ilícito misto, ao mesmo tempo disciplinar e criminal", existindo, portanto, a "possibilidade de optar entre ou até cumular procedimentos criminais e disciplinares".

A Corte chega à importante conclusão de que cabe a ela decidir se a Convenção é aplicável ou não, ainda que o ilícito seja classificado nacionalmente como disciplinar e isto porque se os "estados pudessem, discricionariamente, classificar um ilícito como disciplinar ao invés de criminal, ou processar o autor de um ilícito 'misto' na esfera disciplinar ao invés da esfera penal, a aplicação das cláusulas fundamentais" (da convenção, no caso os artigos 6 e 7) "estariam inteiramente subordinadas à vontade soberana dos estados", o que provavelmente "conduziria a resultados incompatíveis com os objetivos e propósitos da convenção" (p. 31).

O que nos parece especialmente relevante é que a Corte acaba por afirmar que qualquer atividade do estado que tenha como consequência a aplicação de uma punição

63 Disponível em https://hudoc.echr.coe.int/eng-press\#\{\%22itemid\%22:[\%22003-26372792867829\%22]\}

Revista Publicum

Rio de Janeiro, v. 6, n. 1, p. 13-41, 2020

http://www.e-publicacoes.uerj.br/index.php/publicum

DOI: 10.12957/publicum.2020.57571 
de certa gravidade deve ser exercida com o respeito (ainda que não necessariamente na mesma intensidade) a direitos que, embora previstos originalmente (desde as primeiras constituições dos séculos XVIII, XIX) para a esfera penal (na ocasião a única existente ou relevante, até porque o crescimento da máquina administrativa mal tinha se iniciado), na verdade tem como objeto garantir que qualquer punição estatal seja decorrente de um processo justo, independentemente de sua classificação como penal ou não penal.

No caso Sergey a Corte entendeu que o artigo relevante da convenção (artigo 4 do protocolo $7^{64}$ ) "deve ser entendido como proibindo o processo ou julgamento de uma segunda 'violação' sempre que ela decorrer de fatos idênticos ou fatos que sejam substancialmente os mesmos" da primeira. O alcance deste entendimento não pode ser exagerado, pois ele significa dar à VBI uma extensão até agora não reconhecida pelo direito interno de vários países membros da convenção e significa, pura e simplesmente, que um fato só pode ser punido uma única vez. Há que se registrar, no entanto, que para chegar a este resultado é essencial que a sanção não penal seja de gravidade que a aproxime de uma sanção penal (o que, no Brasil, nos parece ser o caso de parte das sanções da Lei de Improbidade e da Lei anticorrupção), pois, do contrário, a Corte não considera violada a VBI.

Mas se a posição da Corte Europeia pode ser lida como mera informação, com caráter (para nós) no máximo doutrinário, importa registrar a posição da Corte Interamericana de Direitos Humanos, a cuja jurisdição o Brasil acedeu, e que vai no mesmo sentido da Corte Europeia.

A Corte Interamericana também tem considerado que a aplicação dos dispositivos originalmente pensados para o processo penal se estende a outros processos não penais. Assim, no caso Maldonado Ordóñez Vs. Guatemala a Corte ressaltou que "as garantias do artigo 8.2 da Convenção não são exclusivas dos processos penais, e podem ser aplicadas a processos de caráter sancionatório".

O caso Loayza vs Peru, de 1997, tratou especificamente da VBI. Tratava-se de uma professora suspeita de atos terroristas absolvida em processo disciplinar e depois processada pelos mesmos fatos na esfera penal. A Corte entendeu que a VBI "busca proteger os direitos de indivíduos que tenham sido processados por determinados fatos para que não voltem a ser processados pelos mesmos fatos. Diferentemente da fórmula utilizada por outros instrumentos internacionais de proteção de direitos humanos (...), a Convenção Americana utiliza a expressão 'os mesmos fatos', que é um termo mais amplo em benefício da vítima".

${ }^{64}$ Reproduzido na nota 2. 
Em decisões posteriores a Corte esclareceu que a submissão de alguém a um 2 은 julgamento não viola a VBI quando o 1 o se limitou a declinar a competência (Caso Lori Berenson Mejía Vs. Perú). Também merece especial destaque o caso Almonacid Arellano y otros Vs. Chile, no qual a Corte afirmou que mesmo a VBI sendo um direito humano reconhecido pela Convenção Americana, "não é um direito absoluto e, portanto, não é aplicável quando: i) a atuação do tribunal que conheceu o caso e decidiu descartá-lo ou absolver o responsável de uma violação dos direitos humanos ou do direito internacional teve o propósito de subtrair o acusado de sua responsabilidade penal; ii) o processo não foi instruído de forma independente ou imparcial em conformidade com as devidas garantias processuais, ou iii) não houve a intenção real de submeter o responsável à ação da justiça"65.

\section{A síntese possível}

A posição da Corte Europeia é resultado de um longo processo de transformação de seu entendimento e, a nosso ver, traz uma versão realmente extremada - embora certamente defensável - da VBI, uma posição que, em geral não é ou não era comum na doutrina e tribunais nacionais dos países europeus. A posição da Corte da Costa Rica, embora vá na mesma linha, talvez não esteja tão consolidada pois é razoável supor que o caráter nitidamente autoritário do regime então vigente no Peru tenha influenciado a corte no precedente específico sobre a VBI. De todo modo, as ressalvas feitas pela Corte nos julgamentos posteriores referidos (quanto à não caracterização de violação da VBI em certas hipóteses, em especial em processos de seriedade duvidosa) são importantes.

Ainda assim, o fato é que ambas as posições estão frontalmente opostas àquela que tem sido escolhida no Brasil ao menos pela legislação infraconstitucional.

A aplicação no Brasil da linha seguida por ambas as cortes traria um risco grande derivado da autonomia das entidades federativas e, portanto, da possibilidade de abertura de processos com o único objetivo de gerar uma absolvição ou punição branda impeditiva de outros processos de responsabilização pelos mesmo fatos, embora este risco tenha sido objeto de preocupação e ressalva por parte da Corte interamericana.

$\mathrm{Na}$ verdade, a autonomia federativa traz, de fato, um complicador a mais à equação (que se encontra presente em maior escala, na aplicação da VBI no caso de punições derivadas de tribunais de distintos países, como já referido acima) que é a dificuldade em impedir a atuação de um ente autônomo em decorrência da atuação de

65 Resumo disponível em http://www.corteidh.or.cr/cf/themis/digesto/digesto.cfm\#_ftn_1_584, acessado em 09.03.2019.

Revista Publicum

Rio de Janeiro, v. 6, n. 1, p. 13-41, 2020

http://www.e-publicacoes.uerj.br/index.php/publicum

DOI: $10.12957 /$ publicum.2020.57571 
outro ente autônomo, o que só pode ser resolvido se entendermos, como é o caso, que a VBI tem status constitucional.

Por outro lado, a possibilidade de cumulação de sanções admitida pela lei anticorrupção nos parece incompatível com a VBI pois significaria a possibilidade de uma sanção penal combinada com mais duas ou três sanções punitivas de outra natureza.

A dificuldade, portanto, está em procurar uma solução entre os dois extremos: um representado pela posição pela qual a VBI impede qualquer segunda punição pelo mesmo fato e outra que admite múltiplas punições decorrentes de múltiplos sistemas de responsabilização pelo mesmo fato, reduzindo-se a VBI a impedir duas punições decorrentes do mesmo fato aplicadas em decorrência do mesmo regime de responsabilização ${ }^{66}$.

Nos parece que a solução mais correta deve ser extraída da previsão dos dois dispositivos constitucionais que afastam a VBI: o artigo $225 \S 3$ e e o $37 \S 4$ o da CRFB. Ambos tratam de exceções constitucionais expressas ao VBI, relativas à proteção de bens jurídicos especialmente sensíveis (o meio ambiente e a moralidade ou probidade públicas) e admitem que uma mesma conduta esteja sujeita a dois processos de responsabilização punitiva (um de natureza penal outro de natureza não penal) além da obrigação de reparar o dano.

Ora, se a VBI, embora implícita, tem natureza constitucional, e se a CRFB houve por bem excepciona-la expressamente no que se refere a regimes protetivos de bens especialmente sensíveis, a contrario sensu a proteção de outros bens, sensíveis ou não, não poderia dar à VBI conteúdo menor do que aquele emprestado pela Constituição.

Portanto, o máximo que se pode admitir na tutela de um bem (sensível ou não) é a sujeição do autor da conduta que o viole a um processo de responsabilização criminal (ainda que não chegue a uma punição) cumulado com outro processo de responsabilização punitiva não criminal, além da obrigação de reparar o dano. Mesmo assim, se eventual sentença penal for absolutória há que se observar as hipóteses nas quais a sentença penal gera efeitos em outras esferas.

Por essa linha, o artigo 30 da Lei anticorrupção, e qualquer outro dispositivo legal que admita a possibilidade de duas ou mais punições não penais, será inconstitucional.

Não se pode desconsiderar, no entanto, que a compatibilidade deste posicionamento com a Convenção Americana de Direitos Humanos não é tranquila. Uma

${ }^{66}$ Para esta posição o mesmo fato poderia gerar uma punição criminal + uma punição com base na lei de improbidade administrativa + uma com base na lei anticorrupção e assim por diante, proibindo apenas que, pelo mesmo fato sejam aplicadas 2 sanções criminais ou 2 sanções com base na lei de improbidade administrativa e assim por diante.

Revista Publicum

Rio de Janeiro, v. 6, n. 1, p. 13-41, 2020

http://www.e-publicacoes.uerj.br/index.php/publicum

DOI: $10.12957 /$ publicum.2020.57571 
alternativa para tornar esta posição mais compatível com a convenção seria considerar que a possibilidade de uma segunda punição (não penal) pelo mesmo fato não deve ser de gravidade tão elevada que represente, materialmente, o equivalente a uma punição penal.

Mas e se o mesmo fato for potencialmente punível por sistemas de responsabilização que tutelam bens jurídicos realmente distintos, seria possível extrapolar os limites que defendemos acima? Tendencialmente não, já que tal posição já é bem menos protetiva do que aquela que decorre da jurisprudência internacional. Ainda assim, podemos registrar que, se for para defender tal compatibilidade, a distinção entre bens jurídicos há de ser clara e inequívoca (e não artificial), o que, por exemplo, não é o caso da sobreposição de punições em matéria de licitação.

É possível que a posição aqui defendida seja mal recebida por distintos lados; pelos que querem ilimitadas punições pelos mesmos fatos e pelos que não admitem nada acima de uma primeira e única punição. A todos só nos resta convidar para um debate a nosso ver realmente necessário para o qual esperamos ter colaborado.

\section{Referências}

AMAR Akhil Reed. The Bill of Rights: Creation and Reconstruction. New Haven \& London: Yale University Press, 1998.

BLAZECK, Luiz Mauricio Souza; MARZAGÃO JÚNIOR, Laerte I. (orgs.), Direito Administrativo Sancionador. São Paulo: Quartier Latin, 2014.

CANOTILHO, J. J. Gomes; BRANDÃO, Nuno. Colaboração premiada e auxílio judiciário em matéria penal: a ordem pública como obstáculo à cooperação com a operação Lava Jato. Revista de Legislação e de Jurisprudência, ano 146 n. 4000, set-out 2016.

CANOTILHO, J. J. Gomes; MOREIRA Vital. Constituição da República Portuguesa: anotada Vol. I, 4 ed. Reimpressão. Coimbra: Coimbra Editora, 2014.

Editora, 2010.

Constituição da República Portuguesa: anotada Vol. II. 4 ed. Coimbra: Coimbra

COSTA, Helena Regina Lobo da. Direito Administrativo Sancionador e Direito Penal: a necessidade de desenvolvimento de uma política sancionadora integrada. In: BLAZECK, Luiz Mauricio Souza; MARZAGÃO JÚNIOR, Laerte I. (orgs.). Direito Administrativo Sancionador. São Paulo: Quartier Latin, 2014.

. Ne bis in idem e Lei Anticorrupção: sobre os limites para a imposição de sanção pelo Estado. Revista Fórum de Ciências Criminais, Belo Horizonte, ano 2, n. 3, p. 73-90, jan./jun. 2015. 
CRYER, Robert, FRIMAN, Håkan, ROBINSON, Darryl, WILMSHURST, Elizabeth. An Introduction to International Criminal Law and Procedure. 3 ed, reprinted. Cambridge: Cambridge University Press, 2015.

DEZAN, Sandro Lucio. Direito administrativo disciplinar: Princípios fundamentais, Curitiba: Juruá, 2013.

DIAS, Augusto Silva. Direito das contra-ordenações. Coimbra: Almedina, 2018.

DI PIETRO, Maria Sylvia Zanella. Direito administrativo. 26 ed. São Paulo: Atlas, 2013.

GARAPON, Antoine, GROS Fréderic, PECH, Thierry. Punir em democracia - E a Justiça será. Lisboa: Instituto Piaget, 2002.

GARCIA, Emerson, ALVES, Rogério Pacheco. Improbidade administrativa. 7 ed., 2 ${ }^{a}$ tiragem. São Paulo: Saraiva, 2014.

GOLDSTONE, Richard. The tension between Combating Terrorism and Protecting Civil Liberties. In: WILSON, Richard Ashby (ed.). Human Rights in the 'War on Terror'. Cambridge: Cambridge University Press, 2005.

GUYOMAR, Mattias. Les sanctions administratives. Paris: LGDJ, 2014.

JORDÃO, Eduardo. Art. 22 da LINDB Acabou o romance: reforço do pragmatismo no direito público brasileiro. Revista de Direito Administrativo - RDA Edição Especial - Direito Público na Lei de Introdução às Normas de Direito Brasileiro - LINDB (Lei no 13.655/2018), p. 63-92, nov. 2018.

JUDT, Tony. Pós-Guerra Uma História da Europa desde 1945. Rio de Janeiro: Objetiva, 2007, p. 734-735.

LASCOUMES, Pierre (org.). Favoritisme et Corruption à la française. Petits arrangements avec la probité. Paris: Presses de Sciences Po, 2010.

LIZZA, Ryan. Secrets, lies, and the N.S.A. The New Yorker, 16 dez 2013, p. 48-61.

MASCARENHAS, Rodrigo Tostes de Alencar. Notas sobre a aplicação do princípio da vedação do bis in idem entre processos de apuração de responsabilidade de distintas naturezas. In: COUTINHO Francisco Pereira e GRACIA, Julia (Coord.). Atas do I Curso sobre Mecanismos de Prevenção e Combate à Corrupção na Administração Pública. Lisboa: Ed. Universidade Nova De Lisboa, 2019, p. 43-70.

. O medo e o ato administrativo. Colunistas n. 289, 2016, disponível em <http://www.direitodoestado.com.br/colunistas/rodrigo-tostes-mascarenhas/o-medo-eo-ato-administrativo>.

MOREIRA NETO, Diogo de Figueiredo. Curso de direito administrativo. 16 ed. Rio de Janeiro: Forense, 2014. 
Poder, Direito e Estado - 0 direito administrativo em tempos de globalização. In memoriam de Marcus Juruena Villela Souto. Belo Horizonte: Fórum, 2011.

MOREIRA NETO, Diogo de Figueiredo e GARCIA, Flavio Amaral. A principiologia no direito administrativo sancionador. Revista Brasileira de Direito Público RBDP, Belo Horizonte, ano 11, n. 43 out/dez 2013.

OLIVEIRA, José Roberto Pimenta. Improbidade administrativa e sua autonomia constitucional. Belo Horizonte: Fórum, 2009.

OSÓRIO, Fabio Medina. Teoria da Improbidade administrativa. São Paulo: RT, 2007.

PEREIRA, Jane Reis Gonçalves. Interpretação Constitucional e Direitos Fundamentais. Rio de Janeiro: Renovar, 2006.

PRADEL, Jean. Droit penal compare. 3 ed. Paris: Dalloz, 2008.

SANTOS, Rodrigo Valgas dos. Direito administrativo do medo. São Paulo: RT, 2020.

SCHREIBER, Anderson. Novos Paradigmas da Responsabilidade Civil. 6 ed. São Paulo: Atlas, 2015.

SOTOMAYOR, Lucía Alarcón. La garantía Non Bis in idem y El procedimento administrativo Sancionador. Madrid: lustel, 2008.

VENÂNCIO, Denilson Marcondes. Non Bis in idem e as Sanções Administrativas por Improbidade e Penal. Revista Trimestral de Direito Público, n. 61, p. 161-186, 2015.

VORONOFF. Alice. Direito Administrativo Sancionador no Brasil. Justificação, Interpretação e Aplicação. Belo Horizonte: Fórum, 2018.

WILSON, Richard Ashby (ed.) Human Rights in the 'War on Terror'. Cambridge: Cambridge University Press, 2005.

Rodrigo Tostes de Alencar Mascarenhas

Professor de Direito Ambiental Constitucional no Curso de Pós-Graduação em Direito Ambiental da PUC/RJ. Doutor em Direito Público pela Universidade de Coimbra, Mestre em Direito Constitucional pela Pontifícia Universidade Católica do Rio de Janeiro - PUC-RJ. Procurador do Estado do Rio de Janeiro e advogado.

Enviado em: 04 de fevereiro de 2021

Aprovado em: 04 de fevereiro de 2021

Revista Publicum

Rio de Janeiro, v. 6, n. 1, p. 13-41, 2020

http://www.e-publicacoes.uerj.br/index.php/publicum

DOI: 10.12957/publicum.2020.57571 